\title{
Timing Fungicide Application Intervals Based on Airborne Erysiphe necator Concentrations
}

L. D. Thiessen, Oregon State University, Department of Botany and Plant Pathology, Corvallis, OR 97331; and T. M. Neill and W. F. Mahaffee, U.S. Department of Agriculture-Agricultural Research Service (USDA-ARS), Horticultural Crops Research Laboratory, Corvallis, OR 97331

\begin{abstract}
Management of grape powdery mildew (Erysiphe necator) and other polycyclic diseases relies on numerous fungicide applications that follow calendar or model-based application intervals, both of which assume that inoculum is always present. Quantitative molecular assays have been previously developed to initiate fungicide applications, and could be used to optimize fungicide application intervals throughout the growing season based on inoculum concentration. Airborne inoculum samplers were placed at one research and six commercial vineyards in the Willamette Valley of Oregon. Fungicide applications in all plots were initiated at the first detection of E. necator inoculum, and all subsequent fungicide application

intervals were made based the grower' standard calendar program or based on inoculum concentration. In adjusted-interval plots, fungicides were applied at the shortest labeled application interval when $>10$ spores were detected and the longest labeled application interval when $<10$ spores were detected. Fungicide applications in control plots consisted of the growers' standard management practice. An average of 2.3 fewer fungicide applications in 2013 and 1.6 fewer fungicide applications in 2014 were used in the adjusted fungicide application intervals treatment in grower fields without significant differences in berry or leaf disease incidence between treatments.
\end{abstract}

Erysiphe necator, the causal agent of grape powdery mildew, causes damage to the foliage and fruit of grape and is an economically important disease worldwide (Calonnec et al. 2004; Cortesi et al. 1997; Gadoury et al. 2012b; Gee et al. 2000; Jarvis et al. 2002). To maintain disease-free fruit, vineyard managers often employ numerous fungicide applications throughout the growing season in conjunction with other cultural practices (Doster and Schnathorst 1985; Ficke et al. 2002). However, over the past several years, viticulturists have encountered economic and political pressures to reduce fungicide use while continuing to produce high-quality fruit under a changing climate that may adversely affect disease dynamics (Chakraborty and Newton 2011; Chakraborty et al. 2008; Chakraborty et al. 2000; Fisher et al. 2012; Pautasso et al. 2012). Additionally, marketing pressures to employ management practices that are considered more environmentally friendly (e.g., organic, biodynamic) have led to the increased utilization of fungicides with limited mobility and persistence, such as sulfur and mineral oil. The increased use of fungicides with limited mobility and persistence further necessitates improved application timing throughout the growing season (Lybbert and Gubler 2008). This dichotomy of reducing fungicide usage while still maintaining a high level of fruit quality creates the opportunity for research methods to optimize fungicide application timing.

Historically, vineyard managers have followed a calendar-based fungicide application program or have utilized disease forecasting models, particularly the UC Davis Risk Index (Gubler et al. 1999), to time fungicide applications. There have been numerous efforts to improve existing disease forecasting models to reduce the frequency of fungicide applications (Caffi et al. 2012; Caffi et al. 2011; Calonnec et al. 2008; Calonnec et al. 2009; Moyer et al. 2010; Moyer et al. 2014; Rossi et al. 2010). However, these disease forecasting models make various assumptions about ascospore maturity (e.g., ascospores are mature at bud break) and the availability of early-season inoculum (e.g., inoculum is available whenever infection conditions are suitable) (Caffi et al. 2011; Carisse et al. 2009a; Carisse et al. 2009b; Gubler et al. 1999). These assumptions may

*Corresponding author: L. D. Thiessen; E-mail: ldthiess@ @csu.edu

Accepted for publication 16 March 2017.

This article is in the public domain and not copyrightable. It may be freely reprinted with customary crediting of the source. The American Phytopathological Society, 2017. cause inaccurate disease predictions in environments different from those in which the empirical correlations were derived (Pscheidt et al. 2000; Thiessen 2016). Assumptions about ascospore release and early-season inoculum availability from disease modeling approaches are also inconsistent with spore sampling data collected in dozens of commercial vineyards in the Pacific Northwest over the last decade (Falacy et al. 2007; Thiessen et al. 2016). Because of the inconsistency in predicting the onset of the disease epidemic and inaccuracy of disease prediction models in western Oregon (Thiessen 2016), unnecessary or untimely fungicide applications may be made (Pscheidt et al. 2000). Near real-time inoculum detection methods to manage grape powdery mildew epidemics may further reduce the number of fungicide applications by directing application timing based on actual inoculum quantity.

Inoculum detection, both visual and molecular, has been used to manage disease in various pathosystems, including hop downy mildew, grape powdery mildew, and Botrytis leaf blight of onion (Carisse et al. 2009a; Carisse et al. 2009c; Falacy et al. 2007; Kremheller and Diercks 1983; Royle 1973). Because the visual identification of spores of several fungal pathogens is time consuming and may be difficult due to dehydration and occlusion by other airborne particles, DNA technologies have been increasingly pursued to identify airborne inoculum to inform management decisions (Carisse et al. 2009c; Falacy et al. 2007; Rogers et al. 2009; Thiessen et al. 2016). By utilizing air sampling methods and DNA technologies, airborne inoculum of target pathogens can be detected within high quantities of background DNA and subsequently be used as a decision tool for the management of disease in multiple pathosystems (Calderon et al. 2002; Carisse et al. 2009c; Falacy et al. 2007; Mahaffee and Stoll 2016; Rogers et al. 2009; Thiessen et al. 2016; West et al. 2008; West and Kimber 2015). Recently, a quantitative PCR assay and a loop-mediated isothermal amplification (LAMP) assay were developed to detect airborne E. necator (e.g., conidia, ascospores) and used to initiate fungicide applications (Thiessen et al. 2016). In the grape powdery mildew pathosystem, delaying fungicide application until inoculum was detected reduced fungicide applications by about 2.5 applications per growing season in the Pacific Northwest (Thiessen et al. 2016). These methods, while sensitive to low inoculum concentrations, are binary and do not assess relative disease risk due to variable inoculum concentrations.

Accurate and sensitive quantitative molecular assays, such as quantitative PCR (qPCR), have been developed for real-time detection and quantification of numerous plant pathogens (Carisse et al. 2009c; Malvick and Impullitti 2007; Rogers et al. 2009; Thiessen et al. 2016; Zheng et al. 2013). These methods, in conjunction with 
an impaction spore sampler to collect airborne inoculum, allow for direct enumeration of inoculum levels in air samples (Mahaffee and Stoll 2016). This near real-time information could allow for an inoculum concentration threshold to be utilized as risk estimation for potential spore deposition and subsequent germination (Carisse et al. 2009a; Carisse et al. 2009c), and to adjust fungicide application intervals. This approach could also reduce untimely and potentially unnecessary fungicide applications. The purpose of this project was to improve fungicide application timing for grape powdery mildew management by initiating and subsequently adjusting fungicide applications based on an inoculum concentration threshold as determined by airborne inoculum monitoring.

\section{Materials and Methods}

Commercial and research vineyard test sites. Six commercial vineyards and the Oregon State University Botany and Plant Pathology Research Vineyard, Corvallis, within the Willamette Valley of Oregon, contained paired treatment plots consisting of their standard management program (control plot) and an adjusted fungicide interval plot (interval plot). All vineyards were grafted Pinot Noir blocks vertically shoot positioned with various management practices (Table 1). Plots were located in a vineyard block of the manager's choosing, and did not need to be co-located with the impaction spore sampler; however, these plots were often placed in the same location as the sampler. Plot size varied from six 30-m rows to 1 ha, depending on vineyard site. Fungicide programs in both treatments were initiated at first detection of E. necator spores or at the onset of bloom (BBCH 61) (Lorenz et al. 1995), whichever occurred first. In the control plots, fungicides were applied at intervals of the growers' choosing. In the adjusted interval plots, fungicide intervals were maintained at the longest application interval for the fungicide chemistry used by the grower until $\geq 10$ spores were detected on the sampling rods. If spore detections were $\geq 10$ spores, fungicide applications were applied at the shortest application interval as stated on the fungicide label until $<10$ spores were detected, at which point fungicide intervals were lengthened to the longest interval as stated on the fungicide label. A conservative 10 -spore threshold was used because the spatial representation of the sampler within a vineyard is unknown (Mahaffee and Stoll 2016) and, in previous spore sampling experiments, 10 spore detections were observed in fields with less than $1 \%$ leaf incidence (Thiessen et al. 2016). Additionally, it is also possible that over the 3- to 4-day sampling period, spores sampled early in the deployment of spore samplers were no longer detectable using the qPCR assay due to UV degradation of DNA or prolonged exposure to DNA nucleases (Lindahl 1993). All fungicide selections and other management decisions were made by vineyard managers (Table 1). Nontreated control plots for each commercial vineyard were not possible due to the high crop value of wine grapes in Oregon and the potential for interplot interference (Campbell and Madden 1990). The research vineyard was monitored for inoculum in both years of the trial, and was included in the field portion of the trial in 2014 because of the low disease pressure observed in commercial vineyards in 2013 and the ability to ensure that all protocols would be followed. Treatments at the research vineyard were applied to blocks of five 53-m rows with data taken from the middle row. Spore samplers were placed in each of interval plots. Due to presence of adjacent untreated controls, there was extreme disease pressure. Environmental conditions, including relative humidity, leaf wetness, rainfall, and temperature were recorded at 15 -min intervals at all field locations to assess the suitability for disease development using a Pessl iMetos weather station (Pessl Instruments GmbH, Weiz, Austria).

Inoculum detection. Custom impaction spore samplers (Thiessen et al. 2016) were placed at each site in both 2013 and 2014. Vineyard managers were directed to place two impaction spore samplers in vineyard blocks with perennially severe disease or where disease levels were observed to be highest in the previous fall as indicated by heavy cane scarring near the basal nodes. Samplers were placed directly adjacent to the trunk such that the sampling arm of the sampler was within $10 \mathrm{~cm}$ of the trunk or cordon until shoot growth reached $30 \mathrm{~cm}$, and the sampling arm was extended above the canopy for the rest of the growing season (Thiessen et al. 2016). Vineyard managers collected samples and transported rod pairs from spore samplers to collection points for delivery to the lab on the same day. Samples were processed and analyzed with the qPCR assay (described below). Rod pairs were collected and replaced every three to four days (biweekly). Samplers were run continuously from bud break (BBCH 08) to véraison (BBCH 81), from 17 April to 12 August 2013 and from 17 April to 11 August 2014 to capture ascospore release and secondary inoculum release until producers cease fungicide applications. Additionally, at the research vineyard, a paired spore sampler was placed adjacent to the biweekly collected spore sampler, which was collected daily from 17 April to 12 August 2013 and from 17 April to 11 August 2014 to monitor the daily fluctuations of airborne inoculum concentrations.

Table 1. Vineyard location general practices and fungicide applications for both 2013 and 2014 growing seasons

\begin{tabular}{|c|c|c|c|c|c|c|c|}
\hline \multirow[b]{3}{*}{ Field } & \multirow[b]{3}{*}{$\begin{array}{l}\text { Training } \\
\text { system }\end{array}$} & \multirow[b]{3}{*}{ Fungicides $^{\mathbf{a}}$} & \multirow[b]{3}{*}{ Location of samplers } & \multicolumn{4}{|c|}{ Fungicide applications ${ }^{\mathbf{b}}$} \\
\hline & & & & \multicolumn{2}{|c|}{2013} & \multicolumn{2}{|c|}{2014} \\
\hline & & & & $\begin{array}{c}\text { Grower standard } \\
\text { control }\end{array}$ & $\begin{array}{c}\text { Adjusted } \\
\text { interval }\end{array}$ & $\begin{array}{c}\text { Grower standard } \\
\text { control } \\
\end{array}$ & $\begin{array}{c}\text { Adjusted } \\
\text { interval }\end{array}$ \\
\hline V1 & VSP $^{c}$ & Conventional & $\begin{array}{l}\text { Inside adjusted } \\
\text { interval treatment }\end{array}$ & 9 & 5 & 7 & 3 \\
\hline $\mathrm{V} 2$ & VSP & Conventional & $\begin{array}{l}\text { Inside adjusted } \\
\text { interval treatment }\end{array}$ & 7 & 4 & 6 & 4 \\
\hline V3 & VSP & $\begin{array}{l}\text { Organic }(2013) \\
\quad \text { conventional }(2014)^{\mathrm{d}}\end{array}$ & $\begin{array}{l}\text { Inside adjusted } \\
\text { interval treatment }\end{array}$ & 16 & 13 & 6 & 5 \\
\hline V4 & $\mathrm{GDC}^{\mathrm{e}}$ & Conventional & $\begin{array}{l}\text { Inside adjusted } \\
\text { interval treatment }\end{array}$ & 6 & 5 & 5 & 4 \\
\hline $\mathrm{BPP}^{\mathrm{f}}$ & VSP & Organic & Inside standard control & $\complement^{g}$ & - & 6 & 9 \\
\hline V5 & VSP & Organic & $\begin{array}{l}\text { Inside adjusted } \\
\text { interval treatment }\end{array}$ & 11 & 10 & - & - \\
\hline V6 & VSP & Conventional & $\sim 1 \mathrm{~km} \mathrm{NW}$ of plots & - & - & 4 & 4 \\
\hline
\end{tabular}

${ }^{a}$ Vineyards were not directed to use specific fungicide chemistries, and both organic and conventional pesticide vineyards were assessed.

${ }^{b}$ Fungicide programs were initiated at the first detection of inoculum. Differences in fungicide applications between the grower standard control and adjusted interval plots are due to the adjustment of fungicide application intervals.

${ }^{c}$ Vertical shoot positioning.

d Vineyard managers changed from 2013 to 2014, and the vineyard that was participating in the experiment changed from organic pesticide management to conventional pesticides.

e Geneva double curtain.

${ }^{\mathrm{f}}$ BPP indicates research vineyard located at the Botany and Plant Pathology Research Farm. All other fields are commercial vineyards located within the Willamette Valley of Oregon.

g Vineyards that only participated in one year of the study did not provide fungicide application records for the growing season indicated (-). 
Sample rod preparation. Stainless steel 308LSI welding rods (1.1 mm in diameter) (Weldcote Metals, Kings Mountain, NC) were cut to 36-mm lengths, washed, sterilized, and coated in vacuum grease (Thiessen et al. 2016). Rod pairs were stored at room temperature until use. Known positive controls and standard curve samples were generated by suspending E. necator spores from Vitis vinifera cv. 'Chardonnay' vines in $0.05 \%$ Tween 20 (Sigma-Aldrich, St. Louis, MO) in nuclease-free water. A hemocytometer was used to estimate the concentration of the conidia suspension, which was then diluted and 10 to $20 \mu \mathrm{l}$ pipetted onto pairs of coated stainless steel rods such that 100 , 500,1000 , or 10,000 conidia were present on the rods. An eyelash brush was used to hand-transfer conidia to create one and 10 conidia concentrations. The rods were dried in a laminar flow hood, and then either processed, as above, or stored at $-20^{\circ} \mathrm{C}$ until processing.

Quantitative PCR assay. DNA was extracted from rod pairs collected from spore samplers (described above) using the PowerSoil DNA extraction kit (MO BIO Laboratories, Inc., Carlsbad, CA) following the manufacturer's protocol. In addition to field samples, a set of prepared rods containing 500 E. necator conidia was included as an extraction efficiency control. Erysiphe necator primers developed by Falacy et al. (2007) were paired with a TaqMan probe with a minor groove binder (Thiessen et al. 2016). All qPCR reactions where $15 \mu \mathrm{l}$ total volume and contained $7.5 \mu \mathrm{l}$ PerfeCTa qPCR ToughMix (Quanta Biosciences, Gaithersburg, MD), $400 \mathrm{nM}$ final concentrations of each E. necator forward and reverse primers and probe, and 1.5- $\mu 1$ extracted sample DNA. Reactions were carried out using an ABI StepOne Plus qPCR machine (Applied Biosystems, Foster City, CA). All qPCR reactions were performed in triplicate and each reaction plate contained 500 conidia extraction control, 100 and 10,000 conidia positive reaction controls, and template-free negative control. Cycle threshold $\left(\mathrm{C}_{\mathrm{t}}\right)$ analysis was conducted using ABI StepOne software. An automatic baseline was set by the software, and the threshold was manually set to a value of 0.02 to allow for plate-to-plate relative comparison. Conidia concentration was determined for each unknown field sample by identifying the average $C_{t}$ value for each triplicate reaction at which the log-linear phase intercepted the 0.02 threshold value and comparing this value to the standard curve described below. Average $C_{t}$ values of positive controls $(100,500$, and 10,000 conidia) from each 96-well plate were used to confirm the efficiency of each qPCR reaction plate and to assess the suitability of the standard curve for converting $\mathrm{C}_{\mathrm{t}}$ values to conidia concentration. If standard controls had a $C_{t} \pm 1$ compared with the standard curve, the samples were rerun to ensure accurate spore quantification. An E. necator standard curve was developed to determine the relative concentration of unknown samples. The standard curve was generated by creating five independent 10 -fold conidial dilution series on the stainless-steel sampling rods 1 to $1 \times 10^{5}$ conidia as described above. DNA extractions were conducted using the PowerSoil DNA extraction kit. The standard curve was then generated by averaging the $\mathrm{C}_{\mathrm{t}}$ values for each conidia quantity from the five independent DNA extractions.

Disease monitoring. Disease monitoring was initiated as soon as leaf tissue with minimal leaf pubescence had emerged, as leaf pubescence often masks symptoms and can easily be confused with signs of powdery mildew. Each plot was scouted weekly for foliar powdery mildew incidence from 30 May to 1 August 2013 and 27 May to 11 August 2014 (BBCH 20 to BBCH 80) to monitor for disease progress. Incidence was determined by inspecting 10 randomly chosen leaves from each of 50 vines in each treatment plot. Disease severity was not assessed in commercial vineyards in both years due to the low disease incidence observed on foliar tissue before véraison. Disease severity was not assessed in the research vineyard in 2014 when the field treatments were included in the trial due to low disease incidence. In 2014, after the cessation of fungicide applications at véraison, one final visual disease incidence assessment was made postharvest.

The incidence of fruit infection was determined by destructively sampling one grape cluster per vine from 50 vines per plot at the onset of véraison. After collection, clusters were frozen at $-20^{\circ} \mathrm{C}$ until assessment. Clusters were visually assessed for powdery mildew presence both unassisted and microscopically (40x magnification) to account for the industry standard visual disease assessment practice
(Ough and Berg 1979; Stummer et al. 2003) and diffuse colonies (Ficke et al. 2003; Gadoury et al. 2003), respectively. For microscopic analysis, frozen berries were removed from the rachis, and 25 berries were randomly chosen to be assessed. The number of infected berries out of 25 was recorded; a single penetration site observed on a berry was classified as positive for disease.

Each pair of samplers, and the associated vineyard, was treated as the experimental unit because the independent impaction spore sampler represented the unit for a management decision in this experiment. Leaf disease incidence from the interval and control plots were compared using the area under disease progress curve (AUDPC) values using a onetailed Student's $t$ test with R 3.2.1 using the agricolae package (v. 1.2-4, R Foundation for Statistical Computing, Vienna, Austria) to calculate AUDPC values for each vineyard. Berry incidence from paired plots was also compared using a one-tailed Student's $t$ test. Fungicide application records were used to compare the number of fungicides used in adjusted-interval plots and grower-standard control plots.

\section{Results}

Field inoculum and disease monitoring. In both 2013 and 2014, E. necator spores were sampled and enumerated using the qPCR assay at all sites tested (Fig. 1). There was less inoculum observed in 2014 (Fig. 1B) compared with 2013 (Fig. 1A). Inoculum was first detected on 23 May 2013 and 1 May 2014 in commercial vineyards, and disease incidence was not observed until May 30 in commercial vineyards in 2013 and not until after véraison in 2014 (Fig. 1). In 2014, a research vineyard was included in the study to observe the effect of higher inoculum pressure. Inoculum was first detected on 18 April 2014, and disease incidence was first observed on 12 June 2014. Biweekly spore sampler collections were not additive of daily sample collections in either 2013 (Fig. 2A) or 2014 (Fig. 2B), although the daily and biweekly collections showed similar concentration fluctuations during the growing season.

In both years, low leaf disease incidence-less than 4\%-was observed in all commercial vineyards and treatments (Fig. 3). Average AUDPC values from commercial fields of adjusted-interval treatments were $25.08 \pm 11.5$ and control treatments were $22.7 \pm 9.4$ in 2013 (Fig. $3 \mathrm{~A})$. Average AUDPC values from commercial vineyards and the research vineyard of adjusted-interval treatments were $3.0 \pm 3.3$ and control treatments were $1.4 \pm 1.5$ in 2014 (Fig. 3B). The research vineyard AUDPC was 0.74 and 1.92 in the control and adjusted-interval treatment plots, respectively. Adjusted-interval and control leaf disease incidence AUDPC were not significantly different in both $2013(P=$ $0.44)$ and $2014(P=0.31)$. Because disease incidence was near $0 \%$ incidence before véraison in 2014 in commercial vineyards, an end-ofseason (BBCH 89) disease assessment was conducted to determine any differences in disease incidence after fungicide applications ceased. The late season disease assessment showed average leaf disease incidence of $47.2 \% \pm 11.4$ in adjusted-interval treatments and $63.5 \% \pm 13.5$ in control treatments and this difference was significant $(P=0.04)$.

Berry disease assessment. In commercial vineyards, visual inspection of clusters detected less than $0.1 \%$ berry disease incidence while microscopically observed incidence in the adjusted-interval treatment and in control treatment was $3.6 \% \pm 1.47$ and $1.8 \% \pm 1.07$, respectively, in 2013 , and $0.01 \% \pm 0.01$ and $0.3 \% \pm 0.2$, respectively, in 2014. Berry disease incidence was not significantly different between adjustedinterval and control treatments in $2013(P=0.11)$ or $2014(P=$ $0.15)$. In the research vineyard, where disease pressure was much higher than the commercial vineyard, disease incidence was significantly higher $(P=0.02)$ in the control treatment $(50.6 \% \pm 5.7)$ than in the adjusted-interval treatment $(33.2 \pm 4.0)$.

Fungicide applications. Interval plots in commercial vineyards received 2.4 and 1.6 fewer fungicide applications compared with control plots in 2013 and 2014, respectively (Table 1). Although only the adjusted-interval plots should have had altered application intervals in commercial fields, fungicide application intervals were also increased in grower standard plots in commercial vineyards in response to spore concentration reports compared with their usual fungicide schedule. This reduction was observed by comparing fungicide application records provided by growers from previous years 
to records from the trial. A vineyard that participated in inoculum detection research made nine conventional fungicide applications in 2009 compared with five conventional fungicide applications in 2014. Disease and inoculum pressure in the research vineyard was higher than commercial vineyards (Fig. 1), which resulted in three more fungicide applications in the adjusted-interval plots relative to the control plots (Table 1).

\section{Discussion}

In this study, growers were able to reduce the number of fungicide applications made within a growing season and maintain the same level of disease control by adjusting fungicide application intervals based on the concentration of airborne $E$. necator inoculum detected from the qPCR assay. Each reduced fungicide application saves an estimated $\$ 52.6$ per acre (Julian et al. 2008), which equates to saving approximately $\$ 126$ and $\$ 84$ per acre in 2013 and 2014, respectively. Field scouting confirmed that visual leaf disease incidence was maintained below $3 \%$ incidence in both years, and microscopically observed fruit disease incidence was maintained below $4 \%$ in commercial vineyards in both control and adjusted-interval treatments. This level of fruit disease is well below the levels observed by Gadoury et al. (2007) to cause detectable off flavors. All commercial growers that participated in this study reduced the number of fungicide applications while maintaining the level of disease control, which suggests that fungicide applications can be reduced or more optimally timed without decreasing the level of disease control in low disease pressure years. Because the research vineyard was under heavy disease pressure from adjacent nontreated control plots, the number of fungicide applications in the adjusted-interval plots increased compared with the standard calendar-based applications. Although fungicide applications were increased, disease control was significantly improved on fruit in the research vineyard when the site was included in the study in $2014(P=0.02)$. These results indicate that current fungicide programs may not be optimally timed for field-specific climatic conditions that can affect fungal development (Aust and Hoyningen-Huene 1986; Waggoner 1965), and fungicide programs may be improved through adjusting fungicide application intervals based on a spore concentration threshold.

The spore concentration action threshold was chosen based on disease and inoculum monitoring over several years, and a conservative threshold was used in this study for two reasons. The area of the vineyard that is represented by the spore sampler is unknown and likely dynamic based on wind conditions (Mahaffee and Stoll 2016), thus there is potential that the sampler collects an inconsistent fraction of the available inoculum. There is also a potential for spore degradation and PCR inhibitor presence on spore sampler rod pairs. Comparison of daily collections of spore samplers from the research vineyard show that biweekly samples collected from later in the growing season are not additive (Fig. 2), which may indicate that DNA from spores is degraded when exposed to environmental conditions (i.e., sunlight and low humidity), and a biweekly sample detection of 10 spores may underrepresent the true concentration of conidia. Based on the low disease incidence observed in commercial vineyards, it may be possible to utilize a less conservative threshold and further reduce fungicide applications without losing disease control. The loss of quantifiable spores also

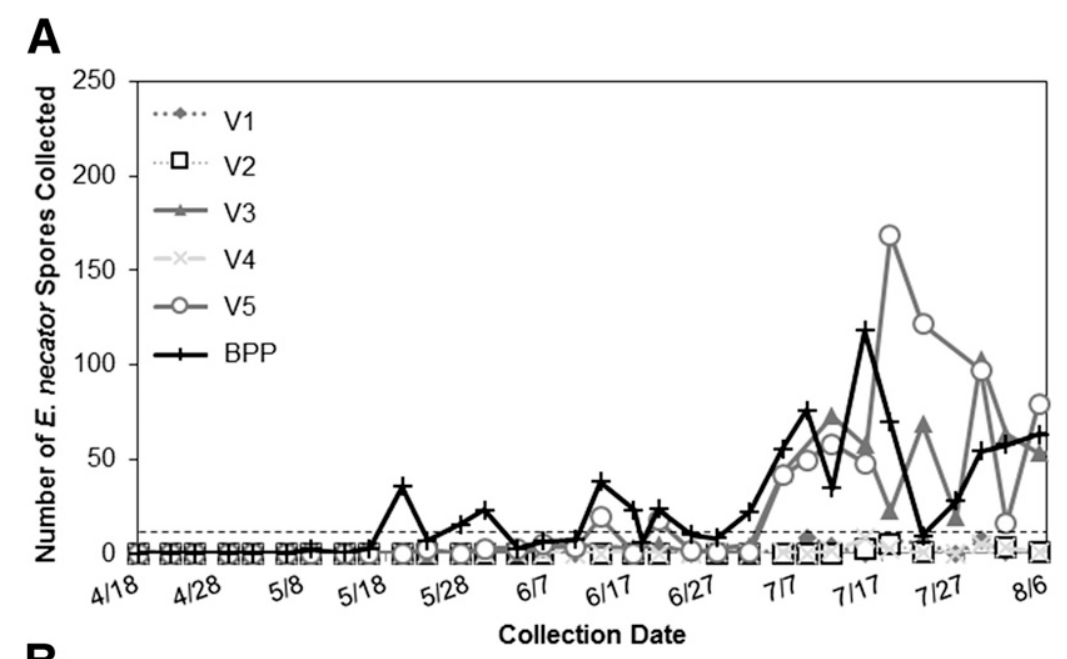

B

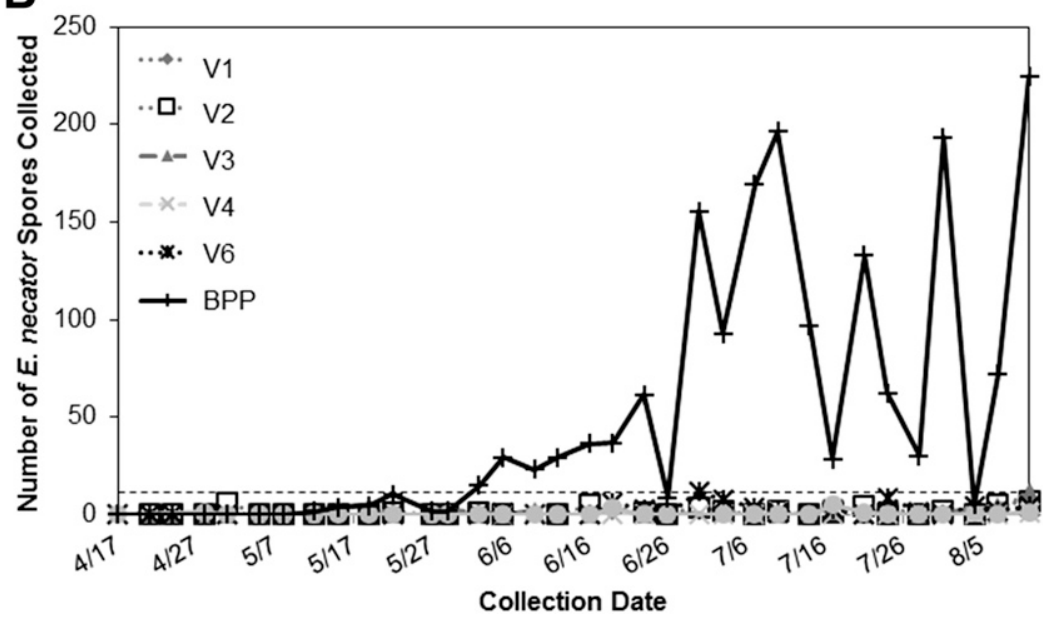

Fig. 1. Erysiphe necator spore concentrations collected from commercial vineyards (V1-V6) and the Botany and Plant Pathology Research Vineyard (BPP) estimated using the quantitative PCR assay in 2013, A, and 2014, B. The BPP vineyard (black cross) spore concentration was monitored in both years, and the site was included in the 2014 field assessment. Vineyards were managed organically (solid lines) or with conventional pesticides (dashed lines). All spore detections at or below the horizontal dashed line are detection concentrations $\leq 10$ spores. 
needs to be taken into consideration when deciding on the sampling interval employed (Fig. 2). Commercial implementation of this technology would be more economically viable if samples could be retrieved every 7 days (as is currently done by some commercial entities in California); however, there could be a risk of inaccurately estimating inoculum concentration due to loss of detectable spores.

The number of spores collected is likely impacted by the placement of the impaction spore sampler within the vineyard, due to microclimate and environmental influences on spore release and dispersal. Fungal spore dispersal and subsequent airborne concentration are dependent on several factors, including spore production and release rate (Gadoury et al. 2012a), colony age (Willocquet et al. 1998), and environmental factors such as wind, temperature, humidity, and precipitation (McCartney et al. 2006; Willocquet et al. 1998). Erysiphe necator conidia appear to achieve escape from leaf surfaces by passive dispersal mechanisms such as wind $(2.3 \mathrm{~m} / \mathrm{s}$ on stationary leaves), leaf movement, intense rainfall, or by turbulence and leaf movement created by high pressure sprayers (Willocquet et al. 1998; Willocquet and Clerjeau 1998). Once spores have become liberated, they travel within the turbulent air mass until they deposit (Isard and Gage 2001). An increased understanding of how turbulent structures are created by complex canopies, such as in vineyards, may improve placement of spore samplers by better predicting inoculum dispersal patterns. Unique turbulence structures within vineyard canopies form eddies and sweeps that influence the direction of particle dispersal (Bailey and Stoll 2013; Bailey et al. 2014; Isard and Chamecki 2016; Miller et al. 2012). These air turbulence structures cause air to channel along the row, regardless of wind direction, with few escapes into the laminar flow layer (Miller et al. 2015, 2017). Placing spore samplers within perennial disease "hotspots"--such as where significant cane scarring near the basal buds is present, in regions with high soil moisture (e.g., low), or shaded regions of the vineyard (Austin and Wilcox 2012; Carroll and Wilcox 2003) - or in the direction of turbulent airflow channeling from "hotspots" in the vineyard may allow for more airborne inoculum to be sampled.

The utility of spore sampling along with spore concentration to time fungicide applications is heavily reliant on spore sampler placement because inoculum release at the onset of the epidemic may go unnoticed if spore samplers are placed in a portion of the vineyard that does not contain overwintering inoculum. The potential rapid generation time (5 days under optimal conditions (Delp 1954)) could result in the epidemic rapidly getting out of control before detection. Spore samplers in this study were placed in regions with heavy cane scarring near basal buds or perennial "hotspots," where overwintering is most likely to occur, in order to sample early spring spore release from cleistothecia or bud perennation. In 2013, one vineyard sampler was not placed according to this protocol. Instead, it was placed, for convenience, adjacent to the winery approximately $4500 \mathrm{~m}$ southwest of the perennial "hotspot" on the other side of a ridge from the managed blocks in a region of the vineyard that was sheltered from the prevailing wind direction. Based on the inoculum concentration at the sampler location, three fewer fungicides applications where made to the adjusted-interval treatment, resulting in more disease than the grower standard. Although this vineyard was removed from the 2013 analysis for failure to follow protocol, the data indicates that monitoring site location is critical to using inoculum monitoring as a decision aid. In this

\section{A}
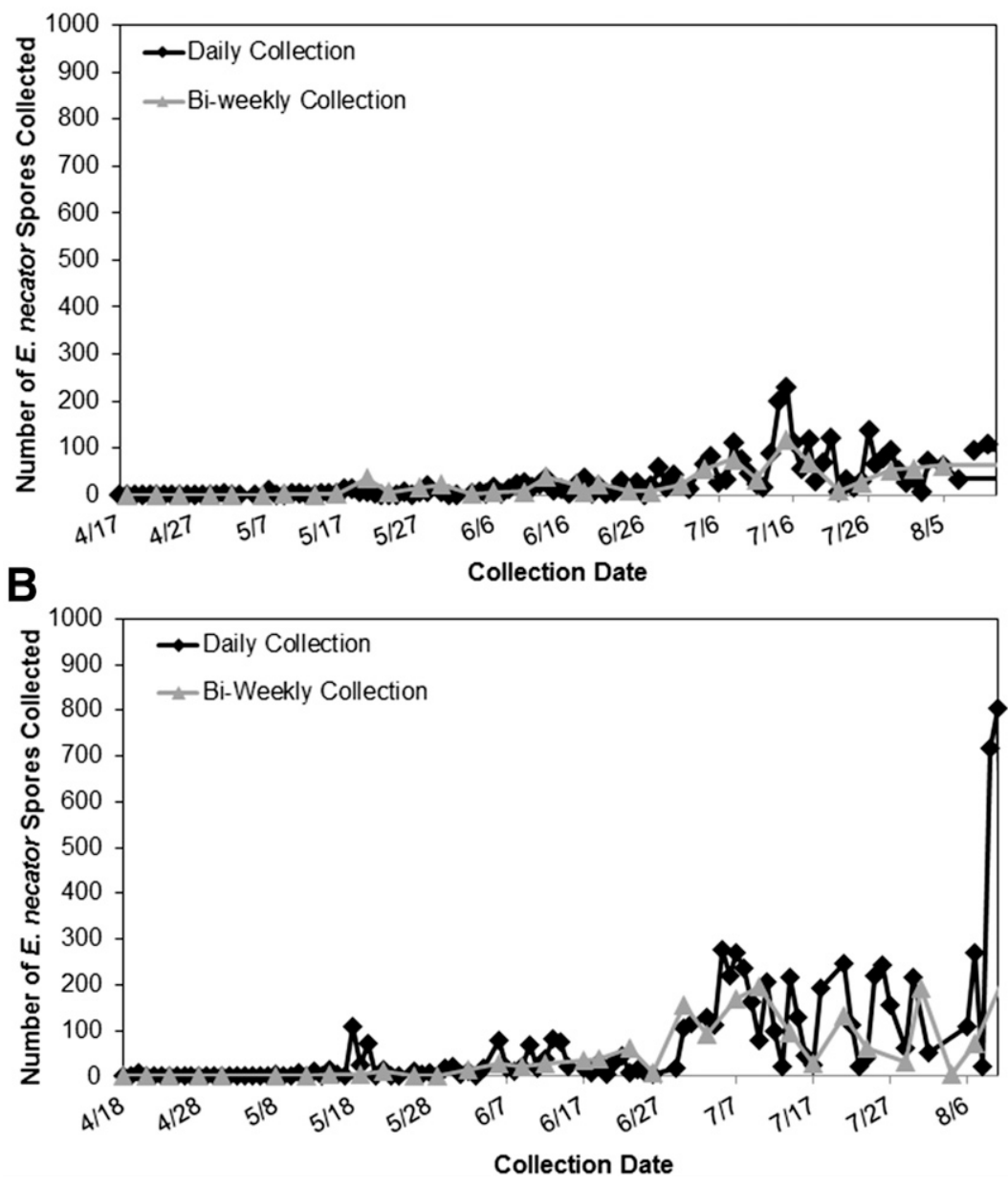

Fig. 2. Erysiphe necator spore concentrations collected from the Botany and Plant Pathology Research Vineyard and estimated using the quantitative PCR assay in 2013, A, and 2014, B. Daily (black diamond) and biweekly (gray triangle) spore concentrations were monitored from bud break (BBCH 08) to véraison (BBCH 81). 
field, berry disease incidence in the adjusted-fungicide application interval plot was $26.7 \%$ compared with $0.3 \%$ incidence in the control plot, and the leaf incidence AUDPC was 191.5 and 0 in the adjustedinterval plot and control plot, respectively. Inoculum was less likely to be detected the farther the spore sampler was placed from the source of inoculum due to the dilution of spore concentration as distance increases from the inoculum source and terrain (Miller et al. 2015; Prussin et al. 2014). Placing the spore sampler nearest to the site with the highest concentration of initial inoculum, primarily cleistothecia within the bark, increases the likelihood that the spore sampler will detect early release events that initiate the epidemic. Placement of spore samplers outside a disease focus may cause underestimation of field-wide spore concentration and disease, whereas placement within a disease focus may potentially overestimate fieldwide spore concentration and disease.

Most vineyards that participated in this study placed their spore samplers within the adjusted-interval plots; however, one vineyard, V6, placed their adjusted-interval and control treatment plots approximately $1 \mathrm{~km}$ from the spore sampler. This vineyard showed no leaf
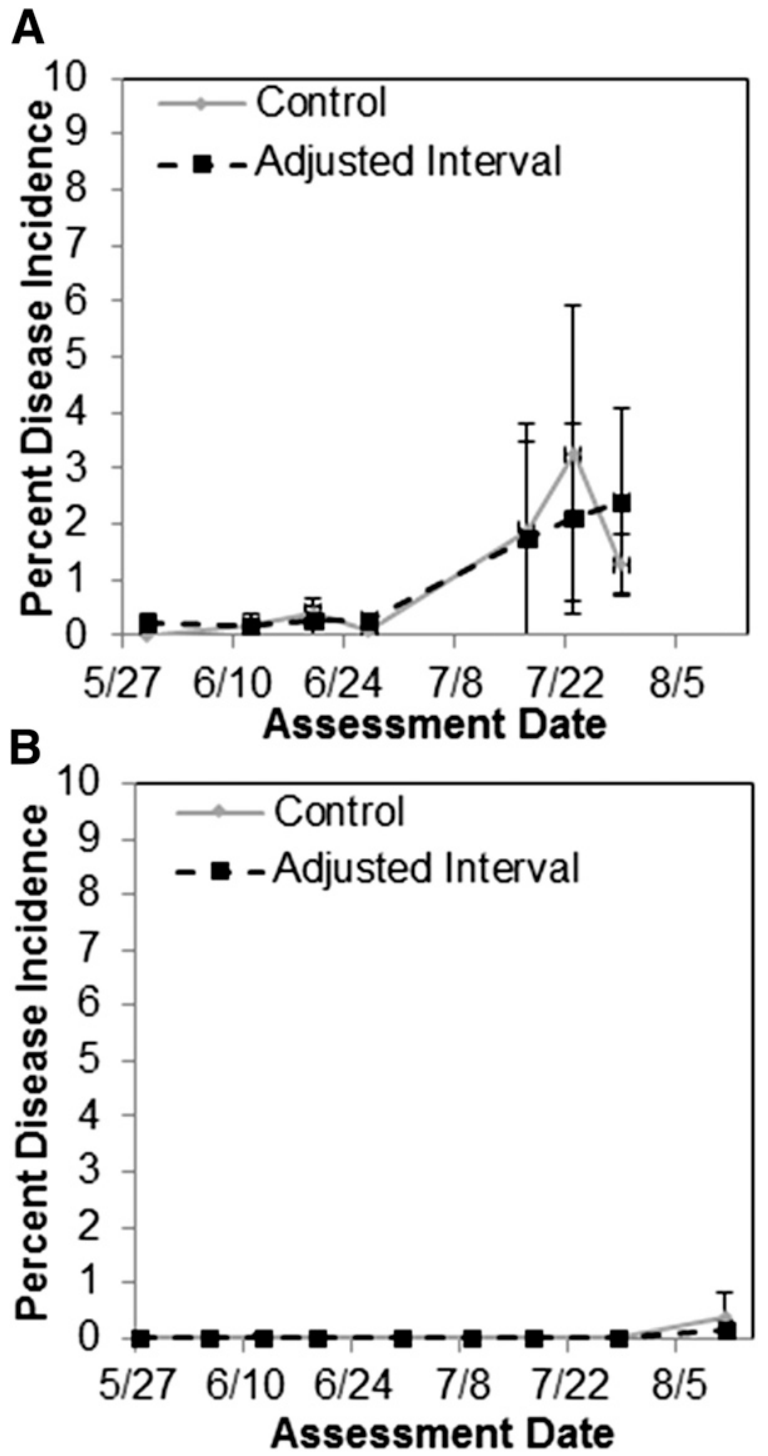

Fig. 3. Grapevine leaf disease percent incidence observed from 6 inches of leaf growth $(\mathrm{BBCH} 20)$ to veraison ( $\mathrm{BBCH}$ 81) from five commercial vineyards in 2013, A, and six commercial vineyards and one research vineyard in 2014, B. A sample of 500 leaves was assessed from the control (solid gray line) or adjusted interval treatment (dashed black line) plot. Error bars are based on the standard error for each data point. One vineyard was removed from the 2013 analysis for failure to follow protocol (described in text). disease incidence in either adjusted-interval or control plots (AUDPC $=0$ ) until after véraison. Including a late leaf disease incidence inspection (BBCH 89), leaf disease incidence AUDPC was 6.1 and 2.65 in adjusted-interval and control plots, respectively. Additionally, berry incidence was not affected by placing the adjusted-interval plots away from the spore sampler, and no disease incidence was observed on berries within either control or adjusted-interval plots for the V6 vineyard. While placement of the spore sampler in a region with a high probability of overwintering inoculum (e.g., cane scaring near the basal nodes) is imperative for early detection of airborne fungal inoculum, it does not appear that the sampler must be located in the block being managed. In previous studies (Thiessen et al. 2016), one grower managed their entire 44.5-ha vineyard (approximately $1700 \times 270 \mathrm{~m}$ ) from a single sampler located in the perennial hot spot. Further exploration of spore dispersal and subsequent deposition within complex canopy architectures and terrain may improve the placement of spore samplers and potentially provide information as to how far away from the spore sampler the quantitative spore concentration data may be applied.

\section{Acknowledgments}

This work was supported by American Vineyard Foundation, Oregon Wine Board, and USDA-ARS CRIS 5358-22000-039-00D. We thank the technical support of Andy Albrecht, Cole Provence, Chris Gorman, and Jim Eynard. We recognize Amy Peetz for designing the quantitative PCR probe. We also thank anonymous reviewers for their helpful suggestions to improve the manuscript. The use of trade, firm, or corporation names in this publication is for the information and convenience of the reader. Such use does not constitute an official endorsement or approval by the United States Department of Agriculture or the Agricultural Research Service of any product or service to the exclusion of others that may be suitable.

\section{Literature Cited}

Aust, H., and Hoyningen-Huene, J. V. 1986. Microclimate in relation to epidemics of powdery mildew. Annu. Rev. Phytopathol. 24:491-510.

Austin, C. N., and Wilcox, W. F. 2012. Effects of sunlight exposure on grapevine powdery mildew development. Phytopathology 102:857-866.

Bailey, B., and Stoll, R. 2013. Turbulence in sparse, organized vegetative canopies: a large-eddy simulation study. Bound.-. Layer Meteor. 147:369-400.

Bailey, B. N., Stoll, R., Pardyjak, E. R., and Mahaffee, W. F. 2014. Effect of vegetative canopy architecture on vertical transport of massless particles. Atmos. Environ. 95:480-489.

Caffi, T., Legler, S. E., Rossi, V., and Bugiani, R. 2012. Evaluation of a warning system for early-season control of grapevine powdery mildew. Plant Dis. 96:104-110.

Caffi, T., Rossi, V., Legler, S. E., and Bugiani, R. 2011. A mechanistic model simulating ascosporic infections by Erysiphe necator, the powdery mildew fungus of grapevine. Plant Pathol. 60:522-531.

Calderon, C., Ward, E., Freeman, J., Foster, S. J., and McCartney, H. A. 2002. Detection of airborne inoculum of Leptosphaeria maculans and Pyrenopeziza brassicae in oilseed rape crops by polymerase chain reaction (PCR) assays. Plant Pathol. 51:303-310.

Calonnec, A., Cartolaro, P., and Chadoeuf, J. 2009. Highlighting features of spatiotemporal spread of powdery mildew epidemics in the vineyard using statistical modeling on field experimental data. Phytopathology 99:411-422.

Calonnec, A., Cartolaro, P., Naulin, J. M., Bailey, D., and Langlais, M. 2008. A host-pathogen simulation model: powdery mildew of grapevine. Plant Pathol. 57:493-508.

Calonnec, A., Cartolaro, P., Poupot, C., Dubourdieu, D., and Darriet, P. 2004 Effects of Uncinula necator on the yield and quality of grapes (Vitis vinifera) and wine. Plant Pathol. 53:434-445.

Campbell, C. L., and Madden, L. V. 1990. Introduction to plant disease epidemiology. Wiley-Interscience, NY.

Carisse, O., Bacon, R., and Lefebvre, A. 2009a. Grape powdery mildew (Erysiphe necator) risk assessment based on airborne conidium concentration. Crop Prot. 28:1036-1044.

Carisse, O., Bacon, R., Lefebvre, A., and Lessard, K. 2009b. A degree-day model to initiate fungicide spray programs for management of grape powdery mildew (Erysiphe necator). Can. J. Plant Pathol. 31:186-194.

Carisse, O., Tremblay, D. M., Lévesque, C. A., Gindro, K., Ward, P., and Houde, A. 2009c. Development of a TaqMan real-time PCR assay for quantification of airborne conidia of Botrytis squamosa and management of Botrytis leaf blight of onion. Phytopathology 99:1273-1280.

Carroll, J. E., and Wilcox, W. F. 2003. Effects of humidity on the development of grapevine powdery mildew. Phytopathology 93:1137-1144.

Chakraborty, S., Luck, J., Hollaway, G., Freeman, A., Norton, R., Garrett, K. A., Percy, K., Hopkins, A., Davis, C., and Karnosky, D. F. 2008. Impacts of global change on diseases of agricultural crops and forest trees. CAB Rev. 3:1-5.

Chakraborty, S., and Newton, A. C. 2011. Climate change, plant diseases and food security: an overview. Plant Pathol. 60:2-14. 
Chakraborty, S., Tiedemann, V., and Teng, P. S. 2000. Climate change: potential impact on plant diseases. Environ. Pollut. 108:317-326.

Cortesi, P., Bisiach, M., Ricciolini, M., and Gadoury, D. M. 1997. Cleistothecia of Uncinula necator-an additional source of inoculum in Italian vineyards. Plant Dis. 81:922-926.

Delp, J. 1954. Effect of temperature and humidity on the grape powdery mildew fungus. Phytopathology 44:615-626.

Doster, M. A., and Schnathorst, W. C. 1985 . Comparative susceptibility of various grapevine cultivars to the powdery mildew fungus Uncinula necator. Am. J. Enol. Vitic. 36:101-104.

Falacy, J. S., Grove, G. G., Mahaffee, W. F., Galloway, H., Glawe, D. A., Larsen, R. C., and Vandemark, G. J. 2007. Detection of Erysiphe necator in air samples using the polymerase chain reaction and species-specific primers. Phytopathology 97:1290-1297.

Ficke, A., Gadoury, D. M., and Seem, R. C. 2002. Ontogenic resistance and plant disease management: a case study of grape powdery mildew. Phytopathology 92:671-675.

Ficke, A., Gadoury, D. M., Seem, R. C., and Dry, I. B. 2003. Effects of ontogenic resistance upon establishment and growth of Uncinula necator on grape berries. Phytopathology 93:556-563.

Fisher, M. C., Henk, D. A., Briggs, C. J., Brownstein, J. S., Madoff, L. C., McCraw, S. L., and Gurr, S. J. 2012. Emerging fungal threats to animal, plant and ecosystem health. Nature 484:186-194.

Gadoury, D. M., Cadle-Davidson, L., Wilcox, W. F., Dry, I. B., Seem, R. C., and Milgroom, M. G. 2012b. Grapevine powdery mildew (Erysiphe necator): A fascinating system for the study of the biology, ecology and epidemiology of an obligate biotroph. Mol. Plant Pathol. 13:1-16.

Gadoury, D. M., Seem, R. C., Ficke, A., and Wilcox, W. F. 2003. Ontogenic resistance to powdery mildew in grape berries. Phytopathology 93:547-555.

Gadoury, D. M., Seem, R. C., Wilcox, W. F., Henick-Kling, T., Conterno, L., Day, A., and Ficke, A. 2007. Effects of diffuse colonization of grape berries by Uncinula necator on bunch rots, berry microflora, and juice and wine quality. Phytopathology 97:1356-1365.

Gadoury, D. M., Wakefield, L. M., Cadle-Davidson, L., Dry, I. B., and Seem, R. C. 2012a. Effects of prior vegetative growth, inoculum density, light, and mating on conidiation of Erysiphe necator. Phytopathology 102:65-72.

Gee, L. M., Stummer, B. E., Gadoury, D. M., Biggins, L. T., and Scott, E. S. 2000. Maturation of cleistothecia of Uncinula necator (powdery mildew) and release of ascospores in southern Australia. Aust. J. Grape Wine Res. 6:13-20.

Gubler, W. D., Rademacher, M. R., Vasquez, S. J., and Thomas, C. S. 1999. Control of powdery mildew using the UC Davis powdery mildew risk index. APS Features doi:10.1094/APSnetFeature-1999-0199.

Isard, S. A., and Chamecki, M. 2016. A physically based theoretical model of spore deposition for predicting spread of plant diseases. Phytopathology 106:244253

Isard, S. A., and Gage, S. H. 2001. Flow of life in the atmosphere. Michigan State Univ., East Lansing, MA.

Jarvis, W. R., Gubler, W. D., and Grove, G. G. 2002. Epidemiology of powdery mildews in agricultural pathosystems. Pages 169-199 in: The Powdery Mildews A Comprehensive Treatise. R. R. Belanger, W. R. Bushnell, A. J. Dik, and T. L. W. Carver, eds. American Phytopathological Society, St. Paul, MN.

Julian, J. W., Seavert, C. F., Skinkis, P. A., Vanbuskirk, P., and Castagnoli, S. 2008. Vineyard economics: Establishing and producing pinot noir wine grapes in western Oregon. OSU Extension Service, Columbus, $\mathrm{OH}$.

Kremheller, H. T., and Diercks, R. 1983. Epidemiology and forecasting of hop downy mildew (Pseudoperonospora humuli). Z. Pflanzenkr. Pflanzenschutz 90:599-616.

Lindahl, T. 1993. Instability and decay of the primary structure of DNA. Nature 362:709-715.

Lorenz, D. H., Eichhorn, K. W., Bleiholder, H., Klose, R., Meier, U., and Weber, E. 1995. Growth stages of the grapevine: Phenological growth stages of the grapevine (Vitis vinifera L. ssp. vinifera)-codes and descriptions according to the extended BBCH scale. Aust. J. Grape Wine Res. 1:100-103.

Lybbert, T. J., and Gubler, W. D. 2008. California wine grape growers' use of powdery mildew forecasts. Giannini Foundation of Agricultural Economics, University of California, Davis.

Mahaffee, W. F., and Stoll, R. 2016. The ebb and flow of airborne pathogens: monitoring and use in disease management decisions. Phytopathology 106: $420-431$.
Malvick, D., and Impullitti, A. 2007. Detection and quantification of Phialophora gregata in soybean and soil samples with a quantitative, real-time PCR assay. Plant Dis. 91:736-742.

McCartney, H. A., Fitt, B. D. L., and West, J. S. 2006. Dispersal of foliar plant pathogens: mechanisms, gradients and spatial patterns. Pages 159-192 in: The Epidemiology of Plant Diseases. B. M. Cooke, D. Gareth Jones, and B. Kaye. S. Netherlands, eds. Springer, The Netherlands.

Miller, N., Gould, A., Stoll, R., Mahaffee, W., and Pardyjak, E. R. 2012. An experimental study of momentum and heavy particle transport in a row-oriented agricultural canopy. Page 2.6 in: 30th Conf. on Agr. and For. Meteorol./1st Conf. on Atmospheric Biogeosci. Am. Meteorol. Soc., Boston, MA

Miller, N. E., Stoll, S., Mahaffee, W. F., and Neill, T. M. 2017. Heavy particle transport in a trellised agricultural canopy during non-row-aligned winds. Agric. Forest Meteorol. (submitted).

Miller, N. E., Stoll, R., Mahaffee, W. F., Neill, T. M., and Pardyjak, E. R. 2015. An experimental study of momentum and heavy particle transport in a trellised agricultural canopy. Agric. For. Meteorol. 211:100-114.

Moyer, M. M., Gadoury, D. M., Cadle-Davidson, L., Dry, I. B., Magarey, P. a., Wilcox, W. F., and Seem, R. C. 2010. Effects of acute low-temperature events on development of Erysiphe necator and susceptibility of Vitis vinifera. Phytopathology 100:1240-1249.

Moyer, M. M., Gadoury, D. M., Wilcox, W. F., and Seem, R. C. 2014. Release of Erysiphe necator ascospores and impact of early season disease pressure on Vitis vinifera fruit infection. Am. J. Enol. Vitic. 65:315-324.

Ough, C., and Berg, H. 1979. Powdery mildew sensory effect on wine. Am. J. Enol. Vitic. 30:321-321

Pautasso, M., Döring, T. F., Garbelotto, M., Pellis, L., and Jeger, M. J. 2012 Impacts of climate change on plant diseases-opinions and trends. Eur. J. Plant Pathol. 133:295-313.

Prussin, A. J., Li, Q., Malla, R., Ross, S. D., and Schmale, D. G., III. 2014 Monitoring the long-distance transport of Fusarium graminearum from fieldscale sources of inoculum. Plant Dis. 98:504-511.

Pscheidt, J. W., Wittig, H. P. P., Wallace, L. D., Hall, T., and Mahaffee, W. 2000. Evaluation of Three Grape Powdery Mildew Forecasting Programs in Corvallis, Oregon, USA. Pages 143-146 in: SARDI Research Report Series. S. A. Margarey Thiele, K. L. Tschirpig, R. W. Emmett, K. Clarke, and R. D. Margarey, eds. SARDI, Adelaide, Australia.

Rogers, S. L., Atkins, S. D., and West, J. S. 2009. Detection and quantification of airborne inoculum of Sclerotinia sclerotiorum using quantitative PCR. Plant Pathol. 58:324-331.

Rossi, V., Caffi, T., Legler, S. E., and Cattolica, U. 2010. Dynamics of ascospore maturation and discharge in Erysiphe necator, the causal agent of grape powdery mildew. Phytopathology 100:1321-1329.

Royle, D. J. 1973. Quantitative relationships between infection by the hop downy mildew pathogen, Pseudoperonospora humuli, and weather and inoculum factors. Ann. Appl. Biol. 73:19-30.

Stummer, B. E., Francis, I. L., Markides, A. J., and Scott, E. S. 2003. The effect of powdery mildew infection of grape berries on juice and wine composition and on sensory properties of Chardonnay wines. Aust. J. Grape Wine Res. 9:28-39.

Thiessen, L. D. 2016. Overwintering of Erysiphe necator and inoculum monitoring for decision aids. Oregon State University, Corvallis, OR.

Thiessen, L. D., Keune, J. A., Neill, T. M., Turechek, W. W., Grove, G. G., and Mahaffee, W. F. 2016. Development of a grower-conducted inoculum detection assay for management of grape powdery mildew. Plant Pathol. 65:238-249.

Waggoner, P. 1965. Microclimate and plant disease. Annu. Rev. Phytopathol. 3: 103-126.

West, J. S., Atkins, S. D., Emberlin, J., and Fitt, B. D. L. 2008. PCR to predict risk of airborne disease. Trends Microbiol. 16:380-387.

West, J. S., and Kimber, R. B. E. 2015. Innovations in air sampling to detect plant pathogens. Ann. Appl. Biol. 166:4-17.

Willocquet, L., Berud, F., Raoux, L., and Clerjeau, M. 1998. Effects of wind, relative humidity, leaf movement and colony age on dispersal of conidia of Uncinula necator, causal agent of grape powdery mildew. Plant Pathol. 47:234-242.

Willocquet, L., and Clerjeau, M. 1998. An analysis of the effects of environmental factors on conidial dispersal of Uncinula necator (grape powdery mildew) in vineyards. Plant Pathol. 47:227-233.

Zheng, Y., Luo, Y., Zhou, Y.,Zeng, X., Duan, X., Cao, X., Song, Y., and Wang, B. 2013. Real-time PCR quantification of latent infection of wheat powdery mildew in the field. Eur. J. Plant Pathol. 136:565-575. 